Proc. Estonian Acad. Sci. Biol. Ecol., 2006, 55, 2, 160-172

\title{
Effect of fertilization with wastewater sludge on the development of Betula pendula seedlings under experimental conditions
}

\author{
Jaan Pikka \\ Harju County Environmental Department, Viljandi mnt. 16, 11216 Tallinn, Estonia; \\ Jaan.Pikka@harju.envir.ee \\ Received 9 December 2005, in revised form 6 March 2006
}

\begin{abstract}
The aim of the experiments was to elucidate the influence of the treatment of alvar and peaty soils with different doses of wastewater sludge on the development of seedlings of silver birch (Betula pendula) under experimental conditions. Sludge from Tallinn Wastewater Treatment Plant used had passed methane fermentation and centrifugal drying. The content of dry matter in the sludge was $50.7 \%$. The concentration of nutrients in the sludge was high: $\mathrm{N} 2.06 \%$, P $2.76 \%$, and K $0.28 \%$. The experiments were conducted on the territory of Tallinn Botanical Garden. For experiments $10 \mathrm{~L}$ plastic pots containing soil and peat mixtures with different concentrations of wastewater sludge $\left(8.9 ; 26.6\right.$, and $44.3 \mathrm{~kg} / \mathrm{m}^{2} \mathrm{~d} . \mathrm{m}$.) and control variants were used.

As a rule, treatment with sludge causes stress in seedlings during the period after planting inhibiting their growth and development. As compared to peat substrates, mineral soils are notably more sensitive towards treatment with wastewater sludge, and stress in plants in the first year is caused by considerably smaller doses of sludge. In spring 2005 the variant with $5 \mathrm{~kg}$ wastewater sludge added to soil per pot died completely; also the variants with $3 \mathrm{~kg}$ sludge added to soil and $5 \mathrm{~kg}$ sludge added to peat should be regarded as dead.

In the second year a positive effect of wastewater sludge was observed in the peat variants. By the end of the second year of growth the morphological parameters of different variants changed significantly. The dry mass was the greatest in the variants with $1 \mathrm{~kg}$ and $3 \mathrm{~kg}$ wastewater sludge added to peat, exceeding the control variant 4.1 and 3.7 times, respectively. In all the variants the proportion of roots in the total dry mass increased.
\end{abstract}

Key words: wastewater sludge, nutrients, Betula pendula.

\section{INTRODUCTION}

The practice of building and operating wastewater treatment facilities has shown that the treatment cycles often remain incomplete. Sludge management tends to be haphazard; no continuously functioning sludge management systems have been introduced. A trustworthy database on the amounts of sludge produced 
in wastewater treatment is lacking. As the concentration of dry matter in the sludge of wastewaters treated in different ways varies, the total amount of sludge can only be estimated. The amount of wastewater sludge produced in Estonia annually is probably $360000-500000$ tonnes. However, as biological treatment of wastewaters and phosphorus removal are expanding in Estonia, the amount of sludge is increasing (Üleriigilise jäätmekava..., 2002). The utilization of sludge is modest; it mostly is used as compost for green areas. Storage of sludge requires large areas but is expensive and involves great environmental risks. Therefore, it is necessary to find new possibilities of using wastewater sludge. As sludge contains large amounts of nutrients needed by plants, one of the options is to use sludge for improving the growth substrate of trees. The effect thus gained would be double: the costs of getting rid of sludge would be replaced by the benefit of additional wood production.

Although it is rich in nutrients, the use of wastewater sludge is complicated. The ratio of nutrients in sludge differs notably from that of natural soils. Its application changes significantly soil reaction and its physical, chemical, and microbiological properties. Therefore, it is necessary to know in what kind of soils and under what conditions wastewater sludge can be used and what the optimum dosages and the most suitable tree species are. It is necessary to ascertain factors disturbing tree growth. Wrong use of sludge may bring forth stress in plants, as they have not developed phylogenetically the necessary protection mechanisms towards unsuitable growth substrate. Therefore the study of the mechanisms of stress resistance of plants has assumed practical importance over and above academic interest. The greater our understanding of plants' response to stress and stress tolerance, the greater will be our ability to manage natural and human-made ecosystems (Mandre, 2002).

Agrochemical properties of Estonia's water treatment plants (Tallinn, Pärnu, Rakvere, Elva, Võru, Haapsalu) have been studied by the Estonian Forest Research Institute. The sludge from all plants studied is characterized by high concentrations of macro- and microelements, including high concentrations of mobile forms of N, P, and K (Tälli, 1991). Tälli \& Riispere (1996) showed that the use of this organic fertilizer has high efficiency in growing decorative trees and bushes (Quercus robur, Aesculus hippocastanum, Ulmus scabra, Crataegus submollis, Cotoneaster lucidus, and Amelanchier spicata) when used in wastewater sludge composts as covering material for new tender seedlings in forest plantations, as a cover fertilizer in tree nurseries, and as a soil improver in making container mixtures. Experiments made in Lithuania revealed that trees and willows showed a good response to fertilization with wastewater sludge on cutaway peatlands (Gradeckas, 1997; Gradeckas et al., 1998). The response of different tree species to different dosages of wastewater sludge is different. Species and hybrids with high demand of nutrients such as Populus tremula, Populus tremula $\times$ P. tremula, $P$. tremuloides $\times P$. tremula, $P$. berolinensis, and Acer negundo had a high productivity when the largest doses (360-720 t/ha d.m.) of wastewater sludge were applied. Betula pubescens showed better growth when the sludge doses were small (180 t/ha d.m.). Betula pendula preferred medium doses (360 t/ha d.m.) and it died 
in the area where the maximum doses ( $720 \mathrm{t} / \mathrm{ha}$ d.m.) were applied (Gradeckas et al., 1998). In experiments carried out on dunes in Latvia with pine, wastewater sludge was applied into the planting holes as a well as used as mulch. Considerably smaller amounts of wastewater sludge - up to $30 \mathrm{t} / \mathrm{ha} \mathrm{d.m.} \mathrm{-} \mathrm{were} \mathrm{used} \mathrm{than} \mathrm{in}$ Lithuania on cutover peatlands. The best results were achieved with application into planting holes of 3-4 $\mathrm{kg}$ per hole (6-8 t/ha d.m.). When larger doses were applied or when sludge was used as mulch the effect was smaller and the time of the effect was shorter (Kāposts et al., 2000, 2001).

\section{MATERIAL AND METHODS \\ Methods of vegetation experiments}

The aim of the experiments was to elucidate the influence of the treatment of alvar and peaty soils with different doses of wastewater sludge on the development of seedlings of silver birch (Betula pendula) under experimental conditions. The field experiments were established on the same soils. Earlier experiments have shown that B. pendula does well in areas treated with wastewater sludge (Gradeckas et al., 1998; Pikka, 2004, 2005). Silver birch is an undemanding species (Tkachenko, 1955; Pihelgas, 1983; Laas, 1987). It is characterized by rapid growth in young age, which after the age of 50-60 years slows down (Rebane, 1974). In 2003 birch was the predominating species by area in Estonian forests growing on $31.2 \%$ of the area (Aastaraamat Mets 2004, 2005).

In developing the methods for the present experiments, the methods of vegetation experiments described by Miidla $(1975,1984)$ were relied upon. The experiments were conducted on the territory of Tallinn Botanical Garden. On 2729 April 2004 vegetation pots were prepared. For experiments $10 \mathrm{~L}$ plastic pots of $27 \mathrm{~cm}$ inner diameter and $20 \mathrm{~cm}$ depth were used. To aid drainage the bottoms of the pots were covered with granite chippings, which were separated from the soil by gauze. For airing and watering a pipe was placed into the drainage. The pots were weighed with electronic weights $(\mathrm{g})$ to guarantee that they all were of the same weight. Next the pots were filled with different mixtures. For the preparation of mixtures alvar and peat soils and wastewater sludge from Tallinn Water Treatment Plant that had been kept in external conditions for half a year were used. All the materials were sieved and carefully mixed.

Sludge from Tallinn Wastewater Treatment Plant used had passed methane fermentation and centrifugal drying. The content of dry matter in the sludge was $50.7 \%$. In sampling Resolution No. 30 of the Minister of the Environment of 6 May 2002 (Proovivõtumeetodid, 2002) was followed. Chemical analysis of the sludge was made at the Agricultural Research Centre. To find the mineral composition of the sludge accredited methods were used: heavy metals were determined with ISO 8288:1986, pH with ISO 10390:1994, dry matter with SFS 3008:1990, and N with ISO 11261. The concentration of nutrients in the sludge was high: $\mathrm{N} 2.06 \%$, P $2.76 \%$, and $\mathrm{K} 0.28 \%$. The $\mathrm{pH}$ of the sludge was 7.1. The concentration of heavy metals was significantly below the permissible limits 
for all elements for which limits have been set. These are discussed in some detail in (Pikka, 2004). Also earlier research on wastewater sludge of Tallinn has shown its low concentration of heavy metals (Tälli et al., 1996). Soil samples for analysing the nutrient elements necessary for trees were collected on 29 April 2004. The soil collected for analysis was dried and sieved through a sieve No. 2. Chemical analysis of the soil was conducted in the Agricultural Research Centre. The following accredited methods were used: pH with ISO 10390:1994, dry matter with SFS 3008:1990, and N with ISO 11261. The concentrations of nutrients in the soil were as follows: $\mathrm{N} 0.44 \%$, $\mathrm{P} 0.22 \%$, and $\mathrm{K} 0.01 \%$; and in the peat: $\mathrm{N} 0.88 \%$, $\mathrm{P} 0.06 \%$, and $\mathrm{K} 0.07 \%$. The $\mathrm{pH}_{\mathrm{KCl}}$ of the soil was 6.9 and of the peat 3.7. After treatment the acidity of the peat was neutralized.

Soil and peat mixtures with different concentrations of wastewater sludge and control variants were used. The following variants were established:

Control I, peat (henceforth P)

- $1 \mathrm{~kg}$ wastewater sludge per pot was added to peat (P1), $8.9 \mathrm{~kg} / \mathrm{m}^{2} \mathrm{~d} . \mathrm{m}$.

- $3 \mathrm{~kg}$ of wastewater sludge per pot was added to peat (P3), $26.6 \mathrm{~kg} / \mathrm{m}^{2}$

- $5 \mathrm{~kg}$ of wastewater sludge per pot was added to peat (P5), $44.3 \mathrm{~kg} / \mathrm{m}^{2}$

Control II, alvar soil (henceforth S)

- $1 \mathrm{~kg}$ wastewater sludge per pot was added to soil (S1), $8.9 \mathrm{~kg} / \mathrm{m}^{2}$

- $3 \mathrm{~kg}$ wastewater sludge per pot was added to soil (S3), $26.6 \mathrm{~kg} / \mathrm{m}^{2}$

- $5 \mathrm{~kg}$ wastewater sludge per pot was added to soil (S5), $44.3 \mathrm{~kg} / \mathrm{m}^{2}$

For all variants soil or peat and sludge were weighed separately for each pot and the materials were carefully mixed. Next the dry matter concentration, total water holding capacity of soil (Wmax), and the concentration of water in soil at $60 \%$ and $70 \% \mathrm{Wmax}$ were determined. Total water holding capacity was determined in the Geotechnical Laboratory of Estonian Environmental Research Centre using the method described by Kitse (1962).

Two-year-old seedlings of Betula pendula were used as experimental material. The seedlings were planted on 6 May 2004. Seedlings of uniform length, root collar diameter, root system, as well as habitus were selected for planting. Three seedlings were planted into each pot. The number of pots in replicates was 15 . All pots were marked and left under external conditions. On 3 June the pots were placed into a cold frame. To get uniform illumination, the pots were placed according to the table of random numbers. During the growing period the pots were continuously transposed. The growth of seedlings depends significantly on soil humidity. The growth is the best when the water holding capacity of the soil is $60-70 \%$ of the total water holding capacity (Miidla, 1984; Raudväli \& Kanger, 1996). Different species have different requirements about the water holding capacity of soil. For several Betula species the optimum range is $60-80 \%$ (Nesterovich \& Deryugina, 1972). In the experiments Wmax was kept at 60-70\% by weighing the pots every day and by adding water as necessary. Together with watering also weeding was conducted.

In autumn 2004 and 2005, after the growth had stopped, the height and height increment with $0.5 \mathrm{~cm}$ precision and root collar diameter with $0.5 \mathrm{~mm}$ precision were measured. In September 2004 one plant was rooted up from each pot, 
altogether five plants from each variant. The trees were divided into four fractions: roots, stem, branches, and leaves. The dry mass of the different plant fractions was immediately measured, and after drying to air-dry condition the dry mass was measured with $0.0005 \mathrm{~g}$ precision. The statistical significance of the data was estimated by $t$-test, $a=0.05$. For statistical analysis the package MS Excel 5.0 was used.

\section{RESULTS}

\section{Effect on the growth of seedlings}

Adaptation of trees to the new environment after planting is characterized by their survival. Significant differences in the development of trees were observed already during the first month after planting. The variants treated with sludge, except P1, adapted to the new conditions worse than the others; part of the trees died. By the autumn of the planting year the largest number of trees had died in the variants P5, S3, and S5, respectively $51.2 \%, 53.3 \%$, and $71.1 \%$ of the trees planted. In spring 2005 the variant S5 died completely; also the variants S3 and P5 should be regarded as dead because only three seedling survived in these variants.

By the end of the first vegetation period clear differences could be observed between the morphological parameters of the seedlings (Table 1). Differences occurred also between the control variants. The birches growing on peat significantly exceeded those growing on alvar soil with respect to height, height increment, root collar diameter as well as dry and fresh mass of the stem and branches. The fresh mass of roots and leaves was practically equal in both control variants; the dry mass of roots and fresh mass of leaves did not show any significant differences either.

Adaptation was the most successful in the case of the variant P1. The height increment of trees of this variant was by $23.5 \%$, the root collar diameter by $12.7 \%$, and dry mass by $149.1 \%$ greater than control. In the case of all soil mixtures

Table 1. Some characteristics of Betula pendula seedlings in September 2004 and in September 2005

\begin{tabular}{|c|c|c|c|c|c|c|}
\hline \multirow[t]{2}{*}{ Treatment } & \multicolumn{2}{|c|}{ Height, $\mathrm{cm}$} & \multicolumn{2}{|c|}{ Increment, cm } & \multicolumn{2}{|c|}{ Root collar diameter, $\mathrm{mm}$} \\
\hline & 2004 & 2005 & 2004 & 2005 & 2004 & 2005 \\
\hline $\mathrm{P}$ & $73.7 \pm 10.2$ & $122.1 \pm 16.1$ & $50.5 \pm 12.1$ & $60.3 \pm 14.1$ & $7.1 \pm 1.0$ & $11.4 \pm 2.0$ \\
\hline $\mathrm{P} 1$ & $86.7 \pm 7.6$ & $191.3 \pm 28.9$ & $62.4 \pm 10.7$ & $111.6 \pm 22.3$ & $8.0 \pm 0.9$ & $16.6 \pm 3.6$ \\
\hline P3 & $59.3 \pm 13.3$ & $161.2 \pm 30.3$ & $37.5 \pm 12.0$ & $103.9 \pm 26.7$ & $5.7 \pm 1.1$ & $13.7 \pm 2.3$ \\
\hline P5 & $31.6 \pm 9.6$ & - & $11.1 \pm 8.6$ & - & $3.7 \pm 0.8$ & - \\
\hline S & $59.2 \pm 5.6$ & $145.8 \pm 15.8$ & $37.6 \pm 5.1$ & $93.7 \pm 14.1$ & $6.1 \pm 0.9$ & $11.9 \pm 2.2$ \\
\hline S1 & $51.3 \pm 12.9$ & $134.1 \pm 18.1$ & $28.2 \pm 12.1$ & $88.1 \pm 14.6$ & $5.6 \pm 1.5$ & $13.1 \pm 3.1$ \\
\hline S3 & $31.7 \pm 6.5$ & - & $9.2 \pm 6.2$ & - & $3.7 \pm 1.0$ & - \\
\hline S5 & $31.3 \pm 7.0$ & - & $11.8 \pm 5.7$ & - & $3.6 \pm 1.2$ & - \\
\hline
\end{tabular}

- The seedlings were dead in spring. 
with wastewater sludge these parameters were lower than of the control variant. The development of trees of the variants of P5, S3, and S5 was disturbed but the differences between their morphological parameters were not statistically significant. Sludge-treated variants, especially those where larger amounts of sludge were applied, showed very great variation. This can be explained by different individual adaptation of trees to unfavourable growth conditions.

By the end of the second year of growth the morphological parameters of different variants changed significantly (Fig. 1a). The dry mass was the greatest

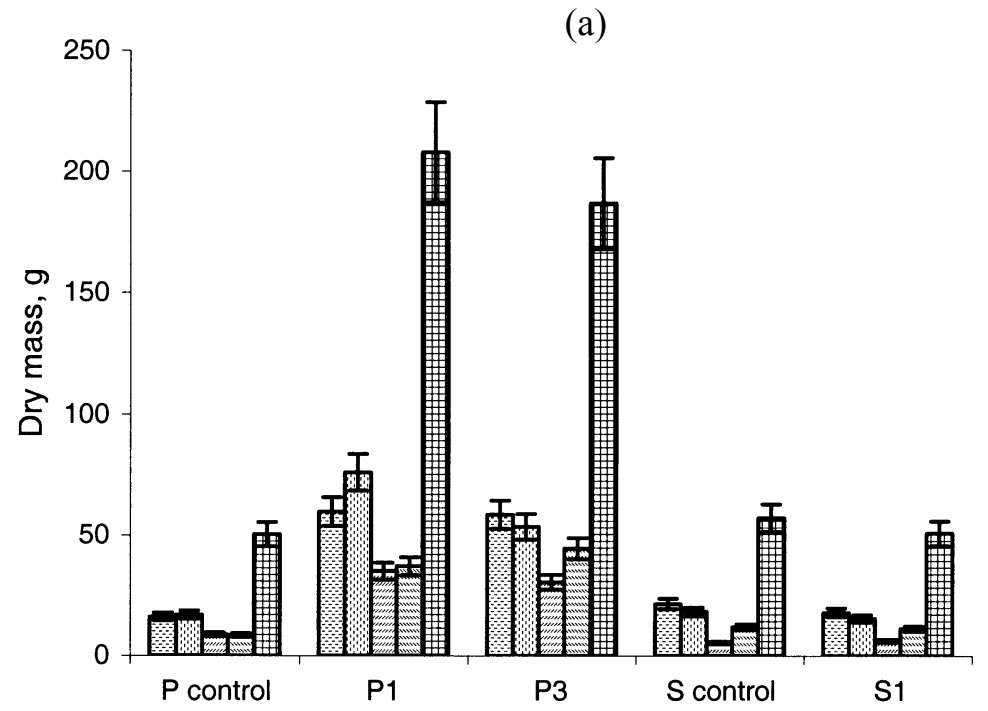

因root

\$stem

四branches

日leaves

田total mass

(b)

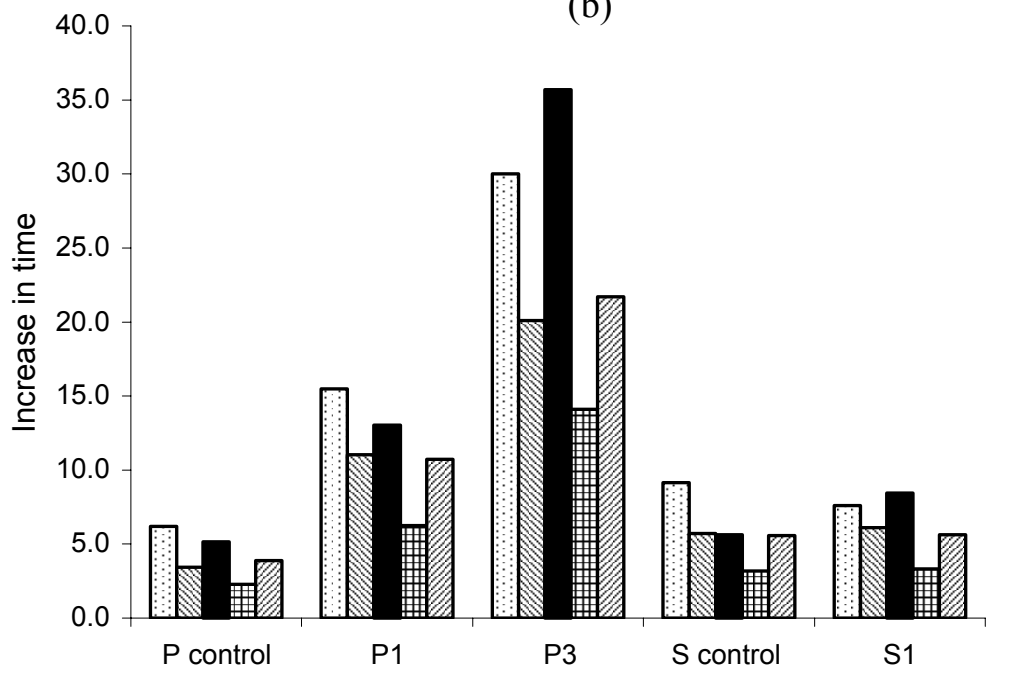

Droot

图stem

branches

田leaves

ฤtotal mass

Fig. 1. Dry mass of different organs of Betula pendula in September 2005 (a) and dry mass increase in September 2005 compared to September 2004 (b). 
in the variants $\mathrm{P} 1$ and $\mathrm{P} 3$, exceeding the control variant 4.1 and 3.7 times, respectively. The fresh mass was the greatest in the variant P3, exceeding the control 4.9 times. As compared to the year 2004, the dry mass of the peat control variant increased 3.9 times, whereas the variant $\mathrm{S} 1$ showed a 10.7 times increase in the dry mass and P3, 21.7 times (Fig. 1b). Thus, as compared with the control variant, the increase in the dry mass of P3 was 5.6-fold and in P1 3.8-fold more intensive. The dry masses of the control variants of peat and soil and of S1 did not differ significantly. The worse performance of the peat control variant can be explained by the fact that although the concentration of nutrients in this variant was higher than in the control variant of soil, it contained notably less nutrients than the rest of the variants, and this amount was insufficient to meet the growth potential of the trees. Valk (1988) considers it necessary that in estimating soil fertility in addition to the relatively high concentration of nutrients also the volume mass of peat should be taken into account.

\section{Influence of treatment with wastewater sludge on the growth of different organs}

As a result of treating the growth substrate with wastewater sludge, the proportion of different organs in the dry mass of trees changes (Fig. 2). The proportion of roots and leaves in the total dry mass of the plants increased, while that of branches and the stem decreased with increasing proportion of sludge in

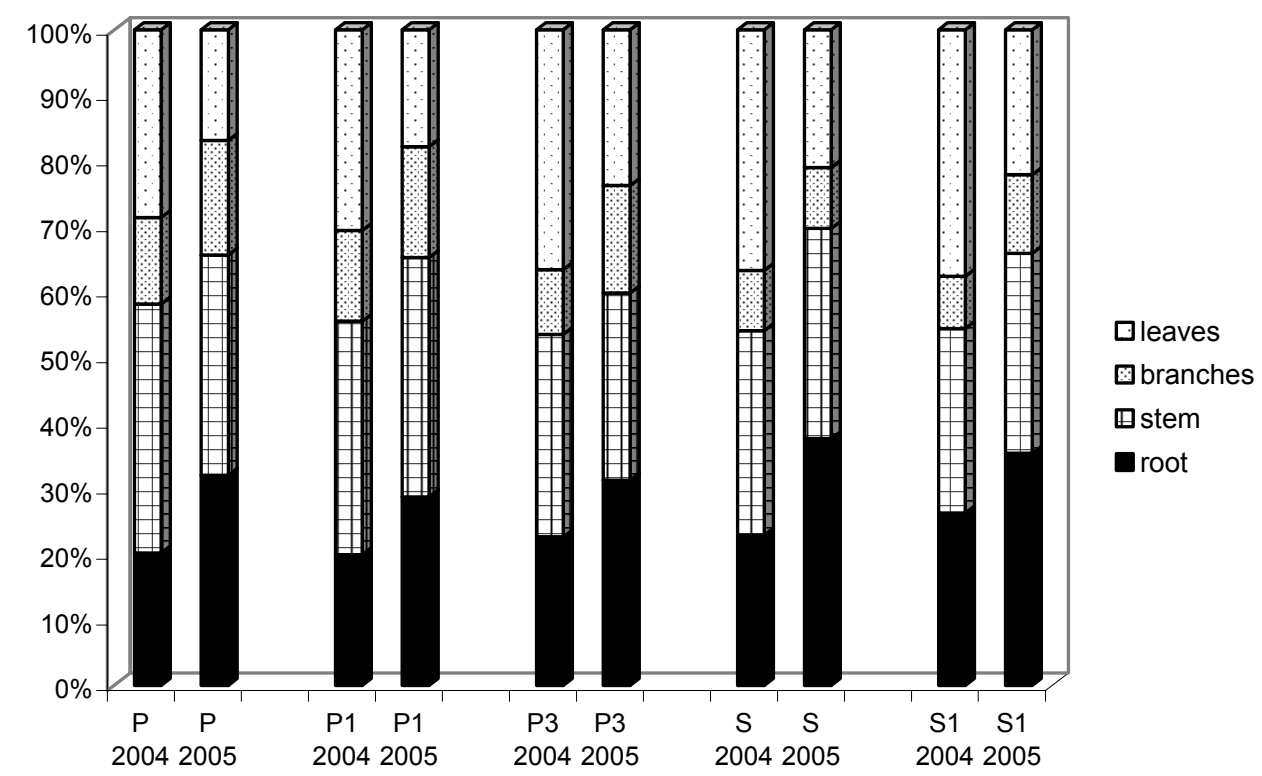

Fig. 2. The proportion of different organs in the dry mass of Betula pendula in September 2004 and in September 2005. 
the growth substrate. As a rule, agricultural crops show increased root and shoot dry mass when nitrogen is applied with shoots growing better (Sattelmacher et al., 1990).

Mineral nutrients are assimilated from the growth substrate by means of roots. Therefore it is especially important how the roots are able to adapt to the new conditions after planting. It should be born in mind that application of wastewater sludge changes significantly the physical, chemical, and microbiological properties of soil. In the first year the greatest root mass was formed in the variant P1, whose dry mass exceeded the peat control variant by $147.9 \%$. The root system of the variant P3 was satisfactory - its dry mass made up $75 \%$ of that of the control variant. The dry mass of the roots of the soil control variant was somewhat smaller than of the peat control variant, but was equal to the variant S1. The root systems of the variants P5, S3, and S5 were very weak: their dry masses were about 3 times smaller than control. The failure of the root system to adapt to unfavourable substrate was revealed in these variants in low survival and morphological parameters. Thus, larger amounts of wastewater sludge applied have an adverse effect on the root system after planting.

Root dry mass is very strongly related to parameters of other organs. In the year after planting a strong correlation existed between the root dry mass and all the other indicators analysed. At the end of the first year of growth the following relationships were found ( $x$ denotes root dry mass):

Dry mass of roots and total dry mass $\quad y=5.337 x-1.8386, \quad R^{2}=0.98$ (biomass)

Dry mass of roots and dry mass of leaves $\quad y=1.645 x-0.3723, \quad R^{2}=0.9868$

Dry mass of roots and dry mass of the stem $y=1.7982 x-0.7535, \quad R^{2}=0.9352$

Dry mass of roots and dry mass of branches $y=1.7556 x-1.3409, \quad R^{2}=0.8938$

Dry mass of roots and height increment $\quad y=1.7524 x-3.262, \quad R^{2}=0.9201$

Dry mass of roots and root collar diameter $\quad y=1.5059 x+2.4907, \quad R^{2}=0.9517$

In the second year of growth the strong relationship was preserved for most of the parameters. The relationship weakened only between the height increment and the root collar diameter. The following relationships were observed:

Dry mass of roots and total dry mass $\quad y=3.5573 x-13.206, \quad R^{2}=0.9919$

(biomass)

Dry mass of roots and dry mass of leaves $\quad y=0.7464 x-3.441, \quad R^{2}=0.9681$

Dry mass of roots and dry mass of the stem $y=1.1774 x-4.8992, \quad R^{2}=0.9212$

Dry mass of roots and dry mass of branches $y=0.6335 x-4.8657, \quad R^{2}=0.9628$

Dry mass of roots and height increment $\quad y=0.705 x+67.029, \quad R^{2}=0.6403$

Dry mass of roots and root collar diameter $\quad y=0.0749+10.74, \quad R^{2}=0.6709$

In the second year the proportion of roots in the total dry matter of birch increased significantly in all variants as compared with the first year. The most intensive root growth was observed in the variant P3, in which the root biomass in the second year was 30 times as large as in the first year. It was twice as large as in the variant $\mathrm{P} 1$ and 4.8 times as large as in the control variant. In the variants P3 and S1 the growth of the dry matter of branches was relatively the most 
intensive. The smallest increment in the dry mass in the second year was observed in the case of leaves.

The effect of treatment with wastewater sludge was especially vivid in the dry mass of various organs. In the roots of plants growing on peat mixtures the proportion of dry mass fell from $36.5 \%$ in the control variant to $28.3 \%$ in the variant P5.

\section{DISCUSSION}

In Latvia application of wastewater sludge was found to have a positive effect on tree growth already in the first year after planting (Kāposts et al., 2000, 2001). The results of the experiments of growing birch seedlings in pots contradict the results of field experiments where in the first year the growth of $B$. pendula seedlings in alvar and peat areas treated with sludge was several times higher than control (Pikka, 2004, 2005). As a difference, it should be noted here that in the field experiments the soil and sludge were harrowed several times before planting test seedlings to secure aeration of the substrate (Pikka, 2004). Cultivation of soils improves their air regime (Kitse, 1963).

For successful afforestation it is necessary to know the reasons that hinder the use of nutrient-rich sludge. Tree growth depends on several factors. The most import among them are temperature, light, precipitation, and soil properties. In the experiments made it was only the chemical and physical characteristics of the substrates that differed. The most important element for plant growth is nitrogen. Regression analysis with all the eight variants showed that there was no relationship between the first-year dry mass of trees and the $\mathrm{N}$ concentration in the substrate. This can be explained by the different concentrations of $\mathrm{N}$ in the substrates. The $\mathrm{N}$ concentrations of peat mixtures were in the range $0.88-1.97 \%$, of soil mixtures, $0.44-1.21 \%$. An increase in the $\mathrm{N}$ concentration cannot be the reason of the inhibited growth and death of trees because the $\mathrm{N}$ concentration in the control variant of peat experiments $-0.88 \%$ - was the same as in the case of $\mathrm{S} 3$ variant in which the trees died. Moreover, the variant P1, which showed the best growth, had a considerably higher $\mathrm{N}$ concentration $-1.13 \%$. In the autumn of the second year a positive relationship was observed between the concentration of $\mathrm{N}$ and dry mass $\left(R^{2}=0.7039\right)$.

As shown above, in the first year almost all parameters of the birches of the control variant of the alvar soil were worse than in the case of the control variant of the peat substrate. The response of trees differed depending on whether the sludge was mixed with peat or soil. In the mixture of wastewater sludge with alvar soil the negative effect on tree growth was observed in the case of significantly smaller amounts of sludge than in the mixture with peat. This suggests that tree growth is affected by physical properties of the substrate. As the moisture conditions were equal in all the variants, the affecting factors should have been primarily soil density and aeration. Peat soils have a significantly lower density than mineral soils (Kask, 1996). They are much better aerated. Aeration of substrate is one 
of the most significant factors affecting plant growth. The importance of air in the substrate is extremely high. The roots of plants and microorganisms living in the soil obtain the oxygen necessary for breathing from the air in the soil and excrete carbon dioxide and other gases into this air. If the oxygen concentration in the substrate falls below $10-15 \%$, the root system cannot develop normally and the starch and sugar concentrations in plants will fall. If the oxygen concentration falls below 9\%, assimilation of nutrients will become hindered (Tõnisson \& Lepind, 1976). When the organic matter applied to soil decomposes, large amounts of $\mathrm{CO}_{2}$, will be released, as a result of which the $\mathrm{CO}_{2}$ concentrations in the air in the soil and near-surface air layers will rise (Raudväli, 1996). In anaerobic conditions the $\mathrm{CO}_{2}$ concentration in soil air may rise to $12-14 \%$ or even higher, and the oxygen concentration may fall to $4 \%$ or even lower. In anaerobic soils the soil air may also contain $\mathrm{CH}_{4}, \mathrm{H}_{2} \mathrm{~S}$, etc. (Kitse, 1963). Microbiological investigations conducted on mineral and peat soils showed that as a result of treatment with wastewater sludge, the amount of denitrifying bacteria increased several times. This indicates poor aeration as for extensive denitrification the following conditions have to be met: poor aeration of the soil, existence of large amounts of nitrates and easily available organic compounds, and $\mathrm{pH}$ 7.0-8.2 (Fedorov, 1960). The soils of the variants $\mathrm{P} 5, \mathrm{~S} 3$, and $\mathrm{S} 5$, in which the seedlings died, met these conditions.

\section{CONCLUSIONS}

Addition of wastewater sludge to growth substrate affects significantly the growth of seedlings. As a rule, treatment with sludge causes stress in seedlings during the period after planting inhibiting their growth and development. Large amounts of wastewater sludge applied may result in the death of birch seedlings. As compared to peat substrates, mineral soils are notably more sensitive towards treatment with wastewater sludge, and stress in plants in the first year is caused by considerably smaller doses of sludge. The processes accompanying the decomposition of organic matter contained in sludge, which significantly aggravate soil aeration, are one of the most important factors inhibiting tree growth. Problems connected with soil air require further research, as these may involve important factors hindering the use of wastewater sludge. Under stress the proportion of roots and leaves in the dry mass of trees increased and that of the stem and branches decreased.

In the second year the growth of trees in all variants intensified. A positive effect of wastewater sludge was observed in the variants P1 and P3, where the increment of dry matter exceeded that of the control variant 4.1 and 3.7 times, respectively. Also, the height increment of trees and root collar diameter were significantly greater. No positive effect of treatment with wastewater sludge on the morphological parameters was observed. In all the variants the proportion of roots in the total dry mass increased. As compared with the first year, the dry mass of roots increased 30 times in the variant P3 and 15.5 times in P1, 6.2 times in the control variant of peat, 9.1 times in the control variant of soil, and 7.6 times in S1. 
The intensive root growth can be explained primarily by the improved mineral nutrition. Mineral nutrient supply can strongly affect root growth, morphology and distribution of root systems in the substrate. This effect is particularly marked with nitrogen, less distinct with phosphorus, and usually absent with other nutrients, except for magnesium (Marschner, 2002).

Additional research is needed on the effect of substrate treatment with sludge on the chemical composition of tree organs. As the treated substrates have high concentrations of nutrients and the ratios of elements differ from the usual ratios, too high concentration of some element(s) cannot be ruled out. Excess of some element in the organs of plants may become dangerous for them (Jones, 1967).

\section{ACKNOWLEDGEMENTS}

The author is grateful to AS Tallinna Vesi and Tallinn Botanical Garden.

\section{REFERENCES}

Aastaraamat Mets 2004. 2005. Keskkonnaministeerium Metsakaitse- ja metsauuenduskeskus, Tartu.

Fedorov, M. V. Microbiology. 1960. Gosudarstvennoe izdatel'stvo sel'skokhozyajstvennoj literatury, Moskva (in Russian).

Gradeckas, A. 1997. Selection of willow clones for energy forests on exploited peatlands, utilising wastewater sludge. Balt. For., 3(1), 24-32.

Gradeckas, A., Kubertavičiene, L. \& Gradeckas, A. 1998. Utilization of wastewater sludge as a fertilizer in short rotation forests on cut away peatlands. Balt. For., 4(2), 7-13.

Jones, J. B., Jr 1967. Interpretation of plant analysis for several agronomic crops. In Soil Testing and Plant Analysis, Part II: Plant Analysis, pp. 49-58. SSSA, Madison, WI.

Kask, R. 1996. Eesti mullad. MATS, Tallinn.

Kāposts, V., Karinš, Z. \& Lazdinš, A. 2000. Use of sewage sludge in forest cultivation. Balt. For., 6(2), 24-28.

Kāposts, V., Karinš, Z. \& Lazdinš, A. 2001. Notekūdeņu dūņu izmantošanas mežsaimnīecībā piredze Latvijā. Mežzinātne, 10(43), 39-54.

Kitse, E. 1962. Mullateaduse laboratoorne praktikum. Eesti Põllumajanduse Akadeemia, Tartu.

Kitse, E. 1963. Mulla vee-, õhu- ja soojusrežiim. Eesti Põllumajanduse Akadeemia, Tartu.

Laas, E. 1987. Dendroloogia. Valgus, Tallinn.

Mandre, M. 2002. Stress concepts and plants. Metsanduslikud uurimused, XXXVI. Tallinn, 9-16.

Marschner, H. 2002. Mineral Nutrition of Higher Plants. Academic Press, Amsterdam.

Miidla, H. 1975. Taimefüsioloogia väikepraktikum. Tartu Riiklik Ülikool, Taimefüsioloogia ja -biokeemia kateeder, Tartu.

Miidla, H. 1984. Taimefüsioloogia. Valgus, Tallinn.

Nesterovich, N. D. \& Deryugina, T. F. 1972. Arboreal Plants and Soil Moisture. Nauka i Tekhnika, Minsk (in Russian).

Pihelgas, E. 1983. Metsabioloogia. Valgus, Tallinn.

Pikka, J. 2004. Reoveesette kasutamisest väheviljakate põllumaade metsastamisel. Metsanduslikud uurimused, 41, 62-72.

Pikka, J. 2005. Use of wastewater sludge for soil improvement in afforesting cutover peatlands. Metsanduslikud uurimused, 42, 95-105.

Proovivõtumeetodid. 2002. Keskkonnaministri määrus nr. 30, 06.05.2002. RTL, 2002, 56, 833. 
Raudväli, E. 1996. Orgaanilised väetised. In Taimede toitumise ja väetamise käsiraamat (Kärblane, H., ed.), pp. 107-145. Eesti Vabariigi Põllumajandusministeerium, Tallinn.

Raudväli, E. \& Kanger, J. 1996. Agrokeemilise uurimise meetodid. In Taimede toitumise ja väetamise käsiraamat (Kärblane, H., ed.), pp. 259-278. Eesti Vabariigi Põllumajandusministeerium. Tallinn.

Rebane, H. 1974. Kask ja kaasikud. In Eesti metsad (Valk, U. \& Eilart, J., eds), pp. 123-131. Valgus, Tallinn.

Sattelmacher, B., Klotz, F. \& Marschner, H. 1990. Influence of the nitrogen level on root growth and morphology of two potato varieties differing in nitrogen acquisition. Plant Soil, 123, 131-137.

Tälli, P. 1991. Reovee muda järeltöötlus. Keskkonnakaitse, 1, 1-6.

Tälli, P. \& Riispere, A. 1996. Kommunaalmuda kasutamisest ilupuude ja -põõsaste kasvatamisel. Metsanduslikud uurimused, 27, 102-111.

Tälli, P., Riispere, A. \& Avatare, L. 1996. Kommunaalmuda kasutamisest mullaviljakuse tõstjana. In Eesti Loodusuurijate Seltsi aastaraamat. Vol. 77, pp. 146-154. Teaduste Akadeemia Kirjastus, Tallinn.

Tkachenko, M. 1955. General Forestry. Goslesbumizdat, Moskva-Leningrad (in Russian).

Tõnisson, H. \& Lepind, Õ. 1976. Mullateaduse õpik. Valgus, Tallinn.

Valk, U. 1988. Eesti sood. Valgus, Tallinn.

Üleriigilise jäätmekava heakskiitmine. 2002. Riigikogu otsus, 04.12.2002. RTI, 23.12.2002, 104, 609.

\section{Reoveesettega väetamise mõju arukase seemikute arengule katsetingimustes}

\section{Jaan Pikka}

Läbiviidud katsete eesmärgiks oli selgitada, kuidas mõjutab loo- ja turvasmuldade töötlemine erinevate jääkmudakogustega arukase seemikute arengut katsetingimustes. Reoveesette lisamine kasvusubstraadile mõjutas oluliselt seemikute kasvu. Reeglina põhjustas muda kasutamine seemikute stressi istutusjärgsel perioodil, mis halvendas puude kasvu ja arengut. Suuremad mudakogused tõid kaasa kaskede hukkumise. Turbamullaga võrreldes on mineraalmullad mudaga töötlemisele tunduvalt tundlikumad ja esimesel kasvuaastal põhjustavad taimede stressi palju väiksemad mudakogused. Üheks olulisemaks puude kasvu pidurdavaks teguriks võib pidada mudas sisalduva orgaanilise aine lagunemisega kaasnevaid protsesse, mille tagajärjel halveneb oluliselt mulla õhustatavus. Mulda viidud orgaanilise aine lagunemisel vabaneb rohkesti $\mathrm{CO}_{2}$, mistõttu rikastuvad mulla õhk ja maapinnalähedased õhukihid $\mathrm{CO}_{2}$-ga (Raudväli 1996). Anaeroobsetes muldades võivad mullaõhus esineda $\mathrm{ka} \mathrm{CH}_{4}, \mathrm{H}_{2} \mathrm{~S}$ jt (Kitse 1963). Mullaõhu küsimused vajavad edasisi uuringuid, sest see võib osutuda oluliseks jääkmuda kasutamist takistavaks teguriks. Stressitingimustes tõusis juurte ja lehtede osatähtsus taimede kuivmassist, langes tüve ja okste osakaal.

Teisel kasvuaastal intensiivistus puude kasv kõigi ellujäänud variantide korral. Reoveesette positiivne mõju ilmnes mudaga töödeldud turbasubstraatidel P1 (turbale lisatud reoveemuda $8,9 \mathrm{~kg} \mathrm{~m}^{-2}$ ) ja P3 (turbale lisatud reoveemuda $26,6 \mathrm{~kg} \mathrm{~m}^{-2}$ ). 
Nende variantide korral ületas kaskede kuivmassi juurdekasv kontrolli oma vastavalt 4,1 ja 3,7 korda. Oluliselt suuremad olid ka puude kõrguse juurdekasv ja juurekaela läbimõõt. Mudaga töötlemise positiivset mõju puude morfoloogilistele näitajatele mullasegudel ei täheldatud. Kõigil variantidel tõusis juurte osatähtsus puude üldmassist. Esimese aastaga võrreldes tõusis variandil P3 juurte kuivmass 30 , variandil P1 15,5, turba kontrollvariandil 6,2, mulla kontrollil 9,1 ja variandil $\mathrm{S} 1$ (mullale lisatud reoveemuda $8,9 \mathrm{~kg} \mathrm{~m}^{-2}$ ) 7,6 korda. Juurte intensiivset kasvu tuleb seostada eelkõige paranenud mineraaltoitumisega, mis mõjutab tugevalt juurte kasvu. See on eriti seotud lämmastiku, kuid vähem fosfori kasutamisega. Teiste toitainetega puudub sageli seos (Marschner 2002).

Täiendavalt vajab uurimist settega töötlemise mõju puude organite keemilisele koostisele. Kuna töödeldud substraadid on suure toitainesisaldusega ja elementide vahekord erineb tavapärasest, ei ole välistatud mõne elemendi kõrge sisaldus taimes, mis võib taime organitele ohtlikuks muutuda (Jones 1967). 